\title{
KOMUNIKASI VERBAL DAN NON VERBAL DALAM JALINAN IKATAN COMMITTED RELATIONSHIP PADA PASANGAN GAY
}

\author{
Novi Andayani Praptiningsih \\ noviap1711@gmail.com \\ UHAMKA, Jakarta
}

\begin{abstract}
This study focuses on verbal and non verbal communication between gay couple in establishing a committed relationship. The conflict consists of internal conflict between the gay couple of different nations and external conflict caused by stigm, discrimination, and bullying is done by the community. This study is a qualitative study using data collection by conducting in-depth interviews and observations of three gay couples. The results showed that gay couples have a specific strategy in maintaining a relationship commitment that reflected through their verbal or nonverbal communication that is tailored to the character of their relationship. Emotional attachment that is going on between the two gay couples could also be a reason for them to maintain their intimacy relationship. Conflict experienced by gay couples, because of jealousy, possessive and aggressive attitudes that dominate one partner, and the presence of one partner's infidelity. While the conflict that occurs as a result of a growing stigma in the community, resulting in discrimination and bullying, such as harassment, humiliation, and violence experienced that same-sex couples.
\end{abstract}

Keywords: Gay, Verbal and Non Verbal Communication, Committed Relationship.

\section{Abstrak}

Studi ini ingin melihat bagaimana komunikasi verbal dan non-verbal terjadi dalam jalinan ikatan committed relationship pasangan gay, dimana ditemukan konflik internal pada pasangan beda bangsa dan konflik eksternal akibat stigma, diskriminasi dan bullying yang dipraktekkan masyarakat. Penelitian kualitif ini dilaksanakan dengan wawancara mendalam dan observasi terhadap tiga pasangan gay. Hasil studi menunjukkan bahwa untuk mempertahankan hubungan, pasangan melakukan strategi khusus dalam bentuk komunikasi verbal dan non-verbal yang akan menunjukkan karakter hubungan mereka. Ikatan emosi diantara pasangan gay menjadi alasan mereka mempertahankan hubungan intim. Konflik mereka terjadi karena kecemburuan, sikap posesif, agresif, dan dan ketidaksetiaan salah satu dari pasangan. Stigma dari keluarga, masyarakat bahkan negara juga mengakibatkan konflik pada pasangan karena mereka mengalami berbagai bentuk penghinaan, pelecehan maupun kekerasan.

Kata kunci: Gay, Komunikasi verbal dan non-verbal, Committed Relationship

orientasi seks. Implikasi dari realitas tersebut dianggap mampu menimbulkan masalah-masalah sosial, sehingga tetap mengundang banyak minat terutama di kalangan para ilmuwan dari berbagai disiplin ilmu untuk melakukan penelitian yang lebih mendalam dan rinci sesuai dengan bidangnya masingmasing. Dengan demikian, sampai saat 
ini tetap masih merupakan sesuatu yang aktual untuk dikemukakan dan dibahas.

Keberadaan kaum gay masih terus diperjuangkan untuk melegalkan pernikahan sejenis. Hingga awal tahun 2015, negara-negara di dunia yang melegalkan pernikahan sejenis dapat dilihat pada Tabel 1.

\section{Tabel 1}

Nama Negara yang Melegalkan

Pernikahan Sejenis

\begin{tabular}{ccc}
\hline No. & NAMA NEGARA & TAHUN \\
\hline $\mathbf{1}$ & Belanda & 2003 \\
\hline $\mathbf{2}$ & Belgia & 2003 \\
\hline $\mathbf{3}$ & Spanyol & 2005 \\
\hline $\mathbf{4}$ & Canada & 2005 \\
\hline $\mathbf{5}$ & Afrika Selatan & 2006 \\
\hline $\mathbf{6}$ & Norwegia & 1993 \\
\hline $\mathbf{7}$ & Swedia & 2008 \\
\hline $\mathbf{8}$ & Portugal & 2010 \\
\hline $\mathbf{9}$ & Islandia & 2010 \\
\hline $\mathbf{1 0}$ & Argentina & 2010 \\
\hline $\mathbf{1 1}$ & Mexico & 2009 \\
\hline $\mathbf{1 2}$ & Uruguay & 2010 \\
\hline $\mathbf{1 3}$ & New Zealand & 2013 \\
\hline $\mathbf{1 4}$ & Perancis & 2013 \\
\hline
\end{tabular}

Beberapa negara bagian di Amerika Serikat juga telah melegalkan pernikahan sejenis. Kedelapan negara tersebut dapat dilihat pada Tabel 2

Namun pada medio 2015, Mahkamah Agung Amerika Serikat mengeluarkan putusan bahwa pasangan sejenis kini memiliki hak untuk menikah. Keputusan yang diambil pada 26 Juni 2015 telah memenangkan gugatan Jim Obergefell, pemimpin kaum LGBT AS yang menyampaikan gugatan agar pernikahan sejenis bisa disahkan di seluruah negara bagian Amerika Serikat. Tuntutannya tersebut dikabulkan oleh
Hakim Anthony Kennedy dengan perbandingan suara lima setuju berbanding empat menolak (dari 9 orang hakim) ini menjadi penanda bahwa penikahan sejenis sah secara hukum nasional di seluruh negara bagian Amerika Serikat, yakni di 30 negara termasuk ibukota Washington DC. Presiden Barrack Obama menyampaikan ucapan selamat atas putusan tersebut, dengan alasan persamaan hak di AS atas semua elemen masyarakat dan komunitas.

\section{Tabel 2}

Nama Negara Bagian di USA yang Melegalkan Pernikahan Sejenis

\begin{tabular}{ccc}
\hline No. & NAMA NEGARA & TAHUN \\
\hline $\mathbf{1}$ & Massachusets & 2004 \\
\hline $\mathbf{2}$ & Connecticut & 2008 \\
\hline $\mathbf{3}$ & Iowa & 2009 \\
\hline $\mathbf{4}$ & Vermont & 2009 \\
\hline $\mathbf{5}$ & New Hampshire & 2010 \\
\hline $\mathbf{6}$ & New York & 2011 \\
\hline $\mathbf{7}$ & Washington DC & 2012 \\
\hline $\mathbf{8}$ & Maryland & 2013 \\
\hline
\end{tabular}

Namun tidak semua hakim dipersidangan tersebut menerima keputusan kontroversial ini. Salah satunya adalah seorang hakim senior di AS, Anthony Scalia yang sejak awal menantang habis-habisan gugatan dari Obergefell dengan asumsi bahwa putusan tersebut berbahaya bagi demokrasi di AS.

Di dunia maya, dukungan atas putusan Mahkamah Agung tentang legalitas pernikahan sejenis ditunjukkan dengan \#LoveWins, \#LoveIsLove, dan \#EqualityForAll. Beberapa brand ternama juga menyatakan dukungannya, bahkan Facebook ikut serta sebagai satu dari sekian banyak entitas bisnis yang mendukung putusan 
legalisasi pernikahan sejenis tersebut dengan mempersembahkan satu tools khusus yang dinamakan "Celebrate Pride", fitur yang memungkinkan penggunanya mewarnai foto profil mereka dengan warna-warni pelangi.

Tom Boellstroff dalam bukunya Gay Archipelago menyatakan bahwa, kaum gay Indonesia sadar bahwa mereka tidak cocok dalam norma-norma budaya dominan, bahkan bila mereka menikah secara heteroseksual (Boellstroff, 2005: 242). Undang-Undang Perkawinan di Indonesia hanya mengatur dan mendefinisikan perkawinan sebagai ikatan antara seorang laki-laki dan seorang perempuan. Maka pasangan macam apa pun, bagaimana pun didasari oleh cinta-kasih tulus, tak mungkin minta peresmian (Oetomo, 2001: 135).

Jumlah perkembangan kaum gay di Indonesia menunjukkan kuantitas yang sangat signifikan yang berkiprah di berbagai kalangan dan profesi. Kiprah kaum gay dahulu hanya terbatas pada dunia entertainment atau salon, namun kini telah merambah pada profesi pendidik, dan berbagai kalangan profesi lainnya.

Dalam melakukan aktivitas atau interaksi dengan pasangan sesama gay, kaum ini memiliki committed relationship, yakni hubungan yang dimiliki oleh dua orang yang tidak hanya melibatkan adanya perasaan dekat sebagai teman atau keluarga melainkan kedua orang tersebut memiliki passion, intimacy, dan committed satu sama lain (Wood, 2004: 294). Dalam tahap ini kedua pasangan sudah merasa nyaman satu sama lain, mereka berdua sudah saling mempercayai dan saling membagi hal yang lebih personal satu sama lain. Akan tetapi pasangan gay masih memiliki privasi yang tidak bisa dibagikan kepada partner yang dimiliki.

Seorang gay akan memiliki kecemasan dan merasa dirugikan karena selalu merasa kurang mendapatkan perhatian dari partnernya. Hal ini akan menciptakan ketidaknyamanan dan kurangnya kehangatan dalam hubungan di antara pasangan gay tersebut. Kecemasan lain yang biasa muncul dalam hubungan pasangan gay ini adalah kecemasan memiliki kondisi commited relationship yang penat. Kepenatan ini biasanya terjadi karena rutinitas yang selalu mereka lakukan sehingga sering terjadi konflik di dalam menjalin hubungan yang akhirnya dapat mengakibatkan berakhirnya hubungan tersebut. Hal lainnya adalah adanya orang ketiga dalam hubungan mereka yang disebabkan karena ketidaksetiaan salah satu pasangan, sehingga menimbulkan rasa cemburu pada pasangannya. Namun konflik tersebut tidak hanya terjadi di ranah internal hubungan mereka saja, konflik juga terjadi pada wilayah eksternal, yakni yang disebabkan adanya stigma, diskriminasi, dan bullying yang dialami oleh pasangan yang sama jenis kelamin ini. Konflik eksternal tersebut dilakukan oleh keluarga, masyarakat, bahkan negara.

Kecemasan akibat konflik internal dapat terjadi karena salah satu seorang gay tidak mendapatkan feedback yang sama seperti stimulus yang diberikan. Jika hal ini terus terjadi maka pasangan gay tidak akan memiliki hubungan yang setara dan membuat antara pasangan yang satu dengan yang lain merasa tidak nyaman (a fulfillment anxiety). Kecemasan tersebut menyebabkan pasangan gay tidak lagi memiliki ketertarikan satu sama lain serta tidak memiliki kedekatan emosional. Pasangan gay ini akan memasuki tahap relationship deterioration. 
Proses relationship deterioration dapat terjadi secara gradual ataupun mendadak. Dalam kondisi ini, bonding dan daya tarik antar pasangan gay. Sedangkan untuk mempertahankan hubungan (committed relationship), daya tarik pasangan dianggap salah satu faktor penting.

Daya tarik ini bisa dilihat dari penampilan maupun sifat dan karakter pasangan gay. Seorang gay terkadang lebih menyukai pasangannya karena warna kulit yang berwarna gelap dan eksotis. Tak jarang pula seorang gay menyukai pasangan mereka karena pasangan tersebut memiliki postur tubuh yang tinggi dan memiliki warna kulit yang putih. Akan tetapi daya tarik ini tidak hanya terbatas dalam bentuk ketertarikan fisik. Melainkan juga ketertarikan karakter, sifat psikologis bahkan materi juga dapat menjadi daya tarik pasangan gay untuk tetap mempertahankan hubungan yang mereka miliki.

Rasa nyaman yang didominasi adanya emotional attachment yang terjadi di antara kedua pasangan gay juga bisa menjadi alasan pasangan gay yang memiliki perbedaan etnis untuk mempertahankan hubungan mereka. Pasangan gay yang sudah memiliki ikatan emosi satu sama lain akan merasakan adanya kenyamanan karena mereka sudah memiliki intimacy dan secara umum pasangan ini tidak mau mencoba mencari partner lain sebagai alternatif.

Berdasarkan latar belakang penelitian di atas, maka rumusan masalah penelitian ini adalah: bagaimanakah komunikasi verbal dan non verbal dalam jalinan ikatan Committed Relationship pada pasangan gay?
Teori yang digunakan dalam penelitian ini adalah Teori Interaksi Simbolik dan Teori Pengungkapan Diri/Self Disclosure, sebagai berikut :

\section{Teori Interaksi Simbolik}

Teori ini memandang aktivitas manusia sebagai suatu aktivitas yang khas berupa komunikasi dengan menggunakan simbol. Perspektif Interaksionisme Simbolik berada di bawah perspektif interpretif (Mulyana, 2006 : 59). Titik tolak pemikiran Interaksi Simbolik berasumsi bahwa realitas sosial sebagai sebuah interaksi simbolik individu-individu yang ada di dalamnya. Pada hakikatnya tiap manusia sebagai proses dan bukan sesuatu yang bersifat statis. Dalam hal ini masyarakat dipandang bukanlah "barang jadi" melainkan barang yang "akan jadi" karena itu teori interaksi simbolik membahas pula konsep mengenai "diri" (self) yang tumbuh berdasarkan suatu "negosiasi" makna dengan orang lain. Menurut George Herbert Mead, cara manusia mengartikan dunia dan dirinya sendiri berkaitan erat dengan masyarakatnya. Mead melihat pikiran (mind) dan dirinya (self) menjadi bagian dari perilaku manusia yaitu bagian interaksinya dengan orang lain. Mead menambahkan bahwa sebelum seorang bertindak, ia membayangkan dirinya dalam posisi orang lain dengan harapan-harapan orang lain dan mencoba memahami apa yang diharapkan orang itu.

Dengan menyerasikan diri dengan harapan-harapan orang lain, dimungkinkan terjadi interaksi. Semakin mampu seseorang mengambil alih atau menerjemahkan perasaan-perasaan sosial semakin terbentuk identitas atau kediriannya. Ada tiga premis yang dibangun dalam interaksi simbolik yaitu: 
1. Manusia bertindak terhadap sesuatu berdasarkan makna-makna yang ada pada sesuatu itu bagi mereka.

2. Makna tersebut berasal dari "interaksi sosial seseorang dengan orang lain".

3. Makna-makna tersebut disempurnakan di saat proses interaksi sosial berlangsung (Kuswarno, 2009:113).

George Ritzer (dalam Mulyana, 2006 : 73) memformulasikan tujuh prinsip yang menjadi inti dari teori interaksionisme simbolik, yaitu:

1. Manusia tidak seperti hewan lebih rendah, diberkahi dengan kemampuan berpikir.

2. Kemampuan berpikir itu dibentuk oleh interaksi sosial.

3. Dalam interaksi sosial, orang belajar makna dan simbol yang memungkinkan mereka menerapkan kemampuan khas mereka sebagai manusia, yakni berpikir.

4. Makna dan simbol memungkinkan orang melanjutkan tindakan (action) dan interaksi yang khas manusia.

5. Orang mampu memodifikasi atau mengubah makna dan simbol yang mereka gunakan dalam tindakan dan interaksi berdasarkan interaksi mereka atas situasi.

6. Orang mampu melakukan modifikasi dan perubahan ini karena, antara lain, kemampuan mereka berinteraksi dengan diri sendiri, yang memungkinkan mereka memeriksa tahapantahapan tindakan, menilai keuntungan dan kerugian relatif, dan kemudian memilih salah satunya.

7. Pola-pola tindakan dan interaksi yang jalin-menjalin ini membentuk kelompok dan masyarakat (Mulyana, 2006 : 73).

\section{Teori Pengungkapan Diri/Self Disclosure}

Menurut Sidney Jourard, usaha menutupi diri dari kelemahan merupakan hal yang harus dilawan, karena orang harus membuka dirinya. Menurutnya, keterbukaan akan dunia dan orang lain merupakan kesadaran, memerlukan keberanian dan kemauan untuk membiarkan orang lain melihat dirinya sebagai mana adanya. Meskipun self disclosure mendorong adanya keterbukaan, namun kleterbukaan itu sendiri ada batasnya. Artinya, perlu pertimbangan kembali apakah menceritakan segala sesuatu tentang diri kita kepada orang lain akan menghasilkan efek positif bagi hubungan sesorang dengan orang lain. Beberapa penelitian menunjukkan bahwa keterbukaan yang ekstrim akan memberikan efek negatif terhadap sebuah hubungan (Littlejohn, 2011 :161).

Proses pengungkapan diri pada lambang verbal dan non verbal terjadi ketika partisipan komunikasi menggunakan kata-kata, baik itu melalui bahasa lisan maupun tulisan. Komunikasi non verbal adalah ketika partisipan komunikasi menggunakan simbol selain kata-kata seperti nada bicara, ekspresi wajah dan sebagainya (Kuswarno, 2009:103).

\section{Gay}

Menurut Siti Musdah Mulia dalam buku Fiqh Seksualitas, Gay adalah laki- 
laki yang memiliki kecenderungan orientasi seksual sesama laki-laki (Musdah, 2011 : vi). (Musdah, 2011 : 25). Foucault (1997:53) mengatakan bahwa gay muncul sebagai salah satu bentuk seksualitas ketika dialihkan dari praktek sodomi menjadi semacam androgini (percampuran dari ciri-ciri maskulin dan feminin) batin (Foucault, $2007: 65$ ).

Gay sering juga disebut sebagai MSM (Men who have Sex with Men), artinya laki-laki yang melakukan aktivitas seksual dengan lelaki lainnya tanpa memandang identitas seksual dirinya di masyarakat atau orientasi seksual yang dimilikinya (Sinyo, 2014 : 7).

\section{Komunikasi Verbal dan Non Verbal}

Pesan verbal dan non verbal dalam sistem sosial, sebagai sarana berbagi pengalaman di antara anggota sistem sosial, merupakan aspek strategis, seperti yang diungkapkan Porter, Samovar, dan Cain (1985 : 134) :"Any verbal or nonverbal language uses symbols that stand for or represent various concrete and abstract parts of our individual realities. These symbols in turn are governed by rules that tels how to use them in order to best represent our experiences".

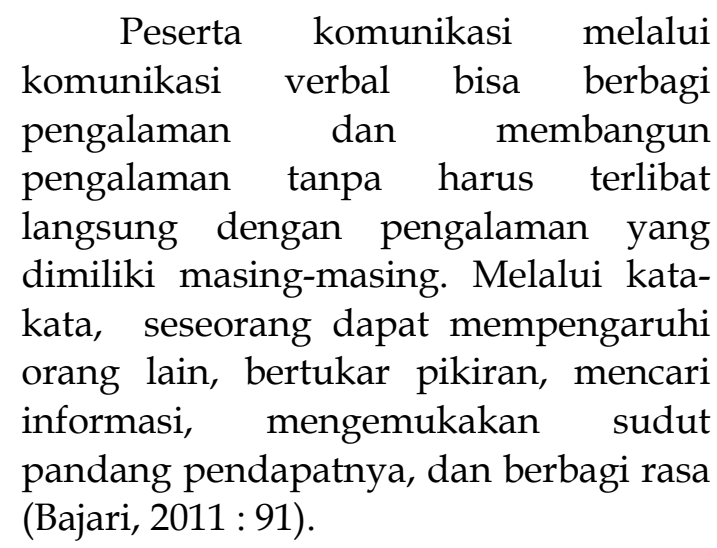

Sedangkan pesan non verbal memiliki kemampuan seefektif pesan verbal, mempertegas pesan verbal, berlawanan atau mengingkari pesan verbal, atau bahkan mewakili pesan verbal itu sendiri. Sebagian besar ahli komunikasi menyebutkan bahwa pesan non verbal memiliki pengaruh lebih besar ketimbang pesan verbal itu sendiri (Bajari, 2011 : 91).

Yang dimaksud dengan komunikasi verbal dalam penelitian ini adalah bagaimana pasangan gay berbeda etnis ini berinteraksi dan berkomunikasi secara intens baik tanpa media (face to face communication/tatap muka), maupun melalui media seperti hp, WA, line, serta media sosial. Sedangkan komunikasi non verbal berupa gesture, posture, dan facial expression yang terjadi di antara pasangan gay saat mereka bertemu dan berinteraksi.

\section{Metode Penelitian}

Penelitian ini menggunakan
pendekatan kualitatif
pendekatan fenomenologis, dengan
teknik pengumpulan data dengan
indepth interview dan observasi terhadap
tiga pasangan gay coming out yang
memiliki committed relationship, serta
telaah dokumen.

Teknik analisis data dalam penelitian ini disusun dengan mengadopsi teknik analisis data kualitiatif yang dikembangkan oleh Miles dan Huberman yaitu analisis model interaktif (interactive model of analysis). Model interaktif ini berfokus pada tiga kompenen. Pertama reduksi data, yaitu proses memilih, menfokuskan, menyederhanakan, dan mengabstraksikan data dari berbagai sumber data, misalnya dari catatan lapangan, dokumen, arsip dan sebagainya. Selanjutnya proses mempertegas, memperpendek, membuang yang tidak perlu, menentukan fokus dan mengatur data 
sehingga kesimpulan bisa dibuat. Kedua, penyajian data, seperti merakit data dan menyajikannya dengan baik supaya lebih mudah dipahami. Penyajian bisa berupa matriks, gambar/skema, jaringan kerja, tabel dan seterusnya. Ketiga, menarik kesimpulan/verifikasi, proses penarikan kesimpulan awal masih belum kuat, terbuka dan skeptis. Kesimpulan akhir dilakukan setelah pengumpulan data berakhir. Verifikasi diperoleh lewat proses negosiasi/ konsensus antar subyek, berdiskusi dengan sejawat, memeriksa data antar anggota. Keseluruhan bagian ini bukan merupakan bagian yang terpisah, namun merupakan satu kesatuan yang saling terkait (Miles dan Huberman, 1992:1621).

\section{Hasil Penelitian}

Tiga pasangan gay dalam penelitian ini, dapat peneliti jabarkan berdasarkan gay orientation, family background, character, communication type, sexual role, ritual, dan relationship bonding threats (lihat Table 3).

\section{Edo - Albert}

Edo adalah seorang gay manly berusia 44 tahun berstatus single, suku Jawa-Indonesia. Edo bekerja sebagai PR Manager sebuah hotel bintang lima di selatan Jakarta. Tanggung jawabnya sebagai seorang PR menuntut Edo untuk selalu standby mengantisipasi jika ada tamu hotel yang complaint atau mengawal event penting yang diselenggarakan hotelnya.

Albert adalah warga negara Australia berusia 50 tahun, dikontrak sebagai pilot oleh sebuah perusahaan penerbangan terbaik Indonesia. Albert mempunyai istri dan seorang anak lakilaki yang berdomisili di Australia, yang rutin bertemu sebulan sekali. Albert adalah seorang gay bisexual yang selain menyayangi keluarganya, Albert juga mencintai Edo.

\section{Dave - Stanley}

Dave adalah seorang gay sissy/feminin berusia 30 tahun, bekerja sebagai Marching Band Trainer di sebuah grup Marching Band terkemuka di Jakarta. Dave yang bersuku ManadoIndonesia juga mengajar sebagai guru musik di sebuah Sekolah Internasional di Jakarta Selatan.

Stanley, berusia 33 tahun adalah seorang dosen (native speaker) di sebuah perguruan tinggi swasta terbaik di Jakarta. Stanley berkebangsaan Canada telah lama menetap di Indonesia. Sebelumnya Stanley yang berorientasi gay manly, bekerja di beberapa lembaga kursus bahasa Inggris ternama di Jakarta.

\section{Anton - Tomi Bun}

Anton berusia 27 tahun adalah seorang gay manly bersuku SundaIndonesia. Anton pernah menikah dengan seorang wanita bukan atas dasar cinta, melainkan desakan keluarganya setelah dirinya lulus S1. Namun hanya bertahan 6 bulan karena sebenarnya Anton tak pernah mencintai istrinya. Anton menyukai laki-laki sejak ia duduk di bangku SMP. Agar tak berlarut-larut membohongi dirinya sendiri dan menyakiti perasaan istrinya, maka Anton memutuskan berterus-terang tentang orientasi seksualnya dan menceraikan sang istri.

Tomi Bun adalah seorang gay bisexual berusia 40 tahun, bekerja sebagai Consultant sebuah perusahaan international oil and gas. Tomi yang keturunan Tionghoa memiliki istri dan dua orang anak, laki-laki dan 
perempuan. Awalnya Tomi menikah demi status karena sebenarnya Tomi tak menyukai perempuan. Namun karena Tomi adalah penganut Budha yang taat, dia berusaha belajar untuk mencintai istrinya. Ketika bertemu dengan Anton yang good looking, Tomi yang vegetarian bergetar hatinya dan akhirnya menjalin hubungan dengan Anton.

\section{Tabel 3}

Committed Relationship Gay Couple

\begin{tabular}{|c|c|c|c|c|c|c|c|}
\hline \multirow[b]{2}{*}{ No } & \multirow[b]{2}{*}{$\begin{array}{c}\text { Identity \& } \\
\text { Criteria }\end{array}$} & \multicolumn{2}{|c|}{ Gay Couple 1} & \multicolumn{2}{|c|}{ Gay Couple 2} & \multicolumn{2}{|c|}{ Gay Couple 3} \\
\hline & & $\begin{array}{c}\text { Indonesian } \\
\text { Gay }\end{array}$ & Partner & $\begin{array}{c}\text { Indonesian } \\
\text { Gay }\end{array}$ & Partner & $\begin{array}{c}\text { Indonesian } \\
\text { Gay }\end{array}$ & Partner \\
\hline 1 & Name & Edo & Albert & Dave & Stanley & Anton & $\begin{array}{l}\text { Tomi } \\
\text { Bun }\end{array}$ \\
\hline 2 & Age & 44 years & 50 years & 30 years & 33 years & 27 years & 40 years \\
\hline 3 & Marital Status & Single & $\begin{array}{c}\text { Married, } \\
1 \\
\text { children }\end{array}$ & Single & Single & Divorce & $\begin{array}{c}\text { Married, } \\
2 \\
\text { children }\end{array}$ \\
\hline 4 & Gay Orientation & Gay Manly & $\begin{array}{c}\text { Gay } \\
\text { Bisexual }\end{array}$ & Gay Sissy & $\begin{array}{l}\text { Gay } \\
\text { Manly }\end{array}$ & Gay Manly & $\begin{array}{c}\text { Gay } \\
\text { Bisexual }\end{array}$ \\
\hline 5 & Occupation & $\begin{array}{l}\text { Hotel } \\
\text { Public } \\
\text { Relations } \\
\text { Manager }\end{array}$ & Pilot & $\begin{array}{l}\text { Marching } \\
\text { Band } \\
\text { Trainer \& } \\
\text { Music } \\
\text { Teacher at } \\
\text { Internatio } \\
\text { nal High } \\
\text { School }\end{array}$ & $\begin{array}{c}\text { Lecturer } \\
\text { (Native } \\
\text { Speaker) } \\
\text { at Privat } \\
\text { Universi } \\
\text { ty }\end{array}$ & $\begin{array}{c}\text { ICT } \\
\text { Enterpre } \\
\text { neur }\end{array}$ & $\begin{array}{c}\text { Consul } \\
\text { tant }\end{array}$ \\
\hline 6 & Nation & $\begin{array}{l}\text { Javanese- } \\
\text { Indonesia }\end{array}$ & Australia & $\begin{array}{l}\text { Manado - } \\
\text { Indonesia }\end{array}$ & Canada & $\begin{array}{l}\text { Sunda nese, } \\
\text { Indone sia }\end{array}$ & Tionghoa \\
\hline 7 & $\begin{array}{c}\text { Family } \\
\text { Background }\end{array}$ & $\begin{array}{l}\text { Happy } \\
\text { Family }\end{array}$ & $\begin{array}{l}\text { Broken } \\
\text { Home }\end{array}$ & $\begin{array}{l}\text { Broken } \\
\text { Home }\end{array}$ & $\begin{array}{l}\text { Happy } \\
\text { Family }\end{array}$ & $\begin{array}{l}\text { Happy } \\
\text { Family }\end{array}$ & $\begin{array}{l}\text { Happy } \\
\text { Family }\end{array}$ \\
\hline 8 & Character & Ambivert & Extrovert & Introvert & Ambivert & Introvert & Extrovert \\
\hline 9 & $\begin{array}{c}\text { Communication } \\
\text { Type }\end{array}$ & Assertive & Possesive & Submisif & Assertif & Possesive & Possesive \\
\hline 10 & Sexual Role & Versatile & $\begin{array}{l}\text { Versatile } \\
\text { Top }\end{array}$ & $\begin{array}{l}\text { Bottom } \\
\text { Only }\end{array}$ & Top Only & - & - \\
\hline 11 & Ritual & $\begin{array}{r}\text { Kissing, Liq } \\
\text { Hard } \mathrm{P} \\
\text { Intercours } \\
\text { Love/ML }\end{array}$ & $\begin{array}{l}\text { It Petting, } \\
\text { tting, } \\
\text { /Making } \\
\text { routine) }\end{array}$ & $\begin{array}{r}\text { Kissing, Lig } \\
\text { Hard P } \\
\text { Intercourse } \\
\text { Love/MI }\end{array}$ & $\begin{array}{l}\text { t Petting, } \\
\text { tting, } \\
\text { /Making } \\
\text { (often) }\end{array}$ & $\begin{array}{r}\text { Relations } \\
\text { chatting an } \\
\text { like spend } \\
\text { together fo } \\
\text { dinner, and } \\
\text { mov }\end{array}$ & $\begin{array}{l}\text { ip only } \\
\text { hangout, } \\
\text { ing time } \\
\text { r sports, } \\
\text { watching } \\
\text { ie. }\end{array}$ \\
\hline 12 & $\begin{array}{c}\text { Relationship } \\
\text { Bonding } \\
\text { Threats }\end{array}$ & $\begin{array}{l}\text { ED often fe } \\
\text { Al spending } \\
\text { his wi } \\
\text { children. } \\
\text { anxiety, be } \\
\text { partner hav }\end{array}$ & $\begin{array}{l}\text { s jelous, if } \\
\text { time with } \\
\text { and } \\
\text { always } \\
\text { ause his } \\
\text { a family. }\end{array}$ & $\begin{array}{r}\text { DV have a } \mathrm{r} \\
\text { another } \mathrm{g} \\
\text { sometimes } \\
\mathrm{DV}\end{array}$ & $\begin{array}{l}\text { lationship } \\
\text { y, so ST } \\
\text { ngry with } \\
\text {. }\end{array}$ & $\begin{array}{l}\text { Emotional bc } \\
\text { of them not } \\
\text { they can es } \\
\text { relationshi } \\
\text { and favoura }\end{array}$ & $\begin{array}{l}\text { nding both } \\
\text { tight. But } \\
\text { joy their } \\
\text { together } \\
\text { le climate. }\end{array}$ \\
\hline
\end{tabular}




\section{Pembahasan}

\section{Edo - Albert}

Komunikasi pasangan gay ini terjadi melalui media jejaring sosial facebook dan membentuk hubungan yang intim. Edo tertarik dengan Albert karena kegagahan dan wajahnya yang rupawan. Sedangkan Albert mampu bertahan membina hubungan dengan Edo karena Edo sangat perhatian dan membuatnya nyaman.

Jika sedang tidak menengok istrinya ke Australia atau saat istri Albert tidak mengunjungi Albert di Indonesia, Albert sering menghabiskan waktu senggangnya bersama Edo. Hal ini karena sikap Edo yang assertive dengan karakter ambivert. Family background Edo yang happy family mampu menenangkan Albert yang berasal dari keluarga broken home karena orangtuanya bercerai, yang kadang membuat Albert tampak possesif.

Komunikasi non verbal dalam ritual mereka adalah kissing, light petting, hard petting, intercourse yang dilakukan secara rutin. Peran seksual Edo yang versatile mampu mengimbangi Albert yang versatile top, sehingga tidak tampak yang lebih dominan di antara mereka. Sedangkan dalam komunikasi verbal, pasangan ini sering mengungkapkan kata-kata romantis sebagai emotional attachment yang merekatkan hubungan mereka. Mereka selalu saling memberi kabar dalam tiap kesempatan, tak ada hari tanpa saling bertelefon dan bertemu. Kecuali Albert sedang menghabiskan waktu bersama anak dan istrinya. Jika Albert sedang terbang ke luar kota, biasanya mereka akan ber-skype melalui laptop untuk menjaga hubungan mereka tetap harmonis.
Konflik internal yang terjadi di antara mereka adalah Edo sering merasa cemburu terhadap Albert ketika Albert sedang bersama istri dan anaknya. Edo juga merasakan cemas (security anxiety) karena khawatir dirinya sudah tak memiliki daya tarik lagi di mata Albert, sehingga Albert meninggalkannya. Namun, rasa cemburu dan cemas Edo dapat diredam oleh Albert, karena mereka senantiasa melakukan hubungan romantis dan ritual intercourse secara rutin. Selama ini, istri dan anak Albert tak mengetahui jika Albert memiliki committed relationship dengan Edo.

Sebagaimana hubungan pasangan heteroseksual, pasangan Edo dan Albert juga mengalami masa "putusnyambung" dalam comitted relationship mereka. Banyak alasan yang menjadi dasar permasalahan "putusnyambung"nya pasangan ini. Akan tetapi karena mereka berdua masih merasa memiliki ketertarikan satu sama lain, mereka memiliki strategi khusus untuk mempertahankan comitted relationship yang mereka miliki. Mengurangi emosi dan mengalah merupakan cara pasangan ini dalam mempertahankan hubungan yang mereka miliki. Albert terbiasa mengurangi emosi ketika bertengkar dengan Edo. Karena merasa Edo masih memiliki daya tarik bagi Albert maka Albert berusaha mengalah untuk mengikuti pilihan yang menjadi hobi maupun minat Edo, contohnya nongkrong, nge-mall atau nonton live music.

Sedangkan konflik eksternal yang dialami oleh pasangan ini ketika mereka sedang membangun suasana romantis ketika dinner, banyak mata pengunjung lain memandang sinis. Pandangan sinis termasuk salah satu bentuk non verbal bullying. 


\section{Dave - Stanley}

Komunikasi verbal yang dilakukan antara Dave dan Stanley cukup intens, karena mereka setiap hari bertemu karena mereka tinggal dalam satu apartemen. Setiap haripun mereka saling bertukar cerita tentang kegiatan mereka masing-masing. Pasangan ini sengaja memilih bertempat tinggal satu apartemen karena mereka ingin menambah intimacy satu sama lain. Jika hari libur, biasanya mereka memiliki kebiasaan makan bersama dan menonton film di bioskop. Selain menonton bioskop dan makan bersama, pasangan ini sering nongkrong di cafe sambil ngopi dan bersenda gurau.

Walau mereka merasa nyaman sehingga memutuskan untuk hidup bersama, namun rutinitas intercourse tidak sesering pasangan Edo dan Albert. Mereka hanya sesekali melakukannya, jika mereka menginginkannya atau salah satu pasangan yang menghendaki.

Stanley kadang mengancam akan pulang ke negaranya dan meninggalkan Dave, karena beberapa kali Stanley memergoki Dave tengah bermesraan dengan gay manly lainnya. Dave yang berasal dari keluarga broken home akan berusaha memperjuangan hubungan mereka. Biasanya dengan kata-kata rayuan yang romantis dan (karena Dave adalah gay sissy), maka Stanley luluh dan mereka lembali berbaikan.

Selain dengan Stanley, Dave juga memiliki hubungan/berselingkuh dengan gay manly lainnya, yaitu teman Dave sesama pelatih Marching Band divisi color guard. Dave dan temannya juga kerap melakukan hubungan seksual dan akhirnya terendus oleh Stanley, sehingga menyebabkan Stanley marah dan cemburu. Jika mereka berkonflik biasanya Dave yang memiliki tipe komunikasi submisif berusaha mengalah, dan Stanley yang assertif dengan bijak akan memaafkannya. Karena sebenarnya mereka adalah pasangan yang cocok. Peran seksual Dave yang bottom only "pas" dengan Stanley yang top only.

Untuk lebih merekatkan hubungan mereka, Stanley sering menemani Dave ketika melatih marching band atau ikut menonton kejuaraan dan tournament marching band nasional dimana Dave menjadi jurinya. Bahkan ketika Dave menjadi official ke luar negeri, Stanley sering ikut serta. Konflik yang kerap terjadi di antara mereka adalah Stanley kadang merasa risih atau keberatan jika Dave sebagai gay sissy terlalu kecimpringan/ngondhek jika mereka sedang di depan umum.

Konflik eksternal yang dialami pasangan ini, berawal ketika mereka memutuskan untuk kontrak rumah bersama. Setelah intens berkomunikasi dan melakukan pendekatan melalui salah satu situs komunitas khusus gay, akhirnya mereka memutuskan untuk tinggal serumah. Namun para tetangga mengusir mereka karena kerap melihat mereka bermesraan di teras rumah. Pengusiran meruapakan salah satu bentuk bullying dan diskriminasi. Sekarang mereka pindah ke rumah susun lantai teratas, dan lebih hati-hati menjaga sikap di depan warga sekitar.

\section{Anton - Tomi Bun}

Anton dan Tomi Bun merupakan salah satu jenis pasangan gay manly dengan gay biseksual berasal dari background keluarga yang keduanya happy family. Karena Anton memiliki sifat 
yang cenderung perfectionist maka secara tidak langsung juga akan memiliki implikasi terhadap sikap dan perhatian Anton dalam mempertahankan comitted relationship. Sesuai dengan pengamatan peneliti selama proses observasi, Anton dan Tomi Bun selalu melakukan komunikasi melalui jejaring sosial facebook maupun telfon walaupun tidak setiap hari, terutama jika Tomi yang memiliki istri dan dua orang anak sudah berada di rumah. Namun kadang kalau rasa kangen terhadap Anton tak terbendung, Tomi akan ke lantai atas unutk sekedar menelfon Anton bisa lebih dari satu jam, atau ke lantai atas unutk sekedar menelfon atau skype Anton bisa lebih dari satu jam.

Ketika ditanyakan kadar rasa cinta terhadap keluarga atau pasangan gaynya, Tomi mengaku lebih enjoy dengan Anton. Karena menurut pengakuan Tomi, rasa nyaman saat bersama Antonlah yang membuat hubungan mereka terus terjalin, walaupun dia juga menyayangi istri dan kedua anaknya.

Ikatan emosional (emotional bonding) antara mereka sebenarnya kurang kuat, karena ritual dalam hubungan mereka tidak pernah dibumbui hubungan seksual. Mereka dapat menikmati dan merasa enjoy dalam suasana yang menyenangkan saat mereka menghabiskan waktu bersama dengan ngobrol, makan bersama, olahraga (renang dan golf) bareng, hang out di cafe, nge-mall, serta menonton bioskop bersama.

Awalnya Anton merasa cemburu saat Tomi bercengkrama dengan istri dan kedua anaknya, namun dengan karakter Tomi yang ekxtrovert mampu meyakinkan Anton yang introvert.
Karena sebenarnya tipe komunikasi mereka sama-sama posesif. Dalam memilih jenis makanan yang akan mereka santap saat hang out, Anton yang bersuku Sunda-Indonesia dan Tomi yang Tionghoa sama-sama menyukai sayuran, karena Tomi adalah seorang vegetarian.

Kebersamaan mereka tak dicurigai sebagai pasangan kekasih oleh istri Tomi, karena sang istri menganggap mereka hanya bersahabat dan wajar jika dua orang sahabat spending time together. Bahkan istri Tomi sering mengajak dinner Anton di rumah mereka, atau saling berkunjung ke rumah masing-masing. Yang mengetahui hubungan mereka berdua hanyalah komunitas gay dimana mereka bergabung menjadi anggotanya.

Konflik di antara Anton dan Tomi relatif jarang, karena menurut mereka tak ada yang bisa dijadikan masalah untuk dipertengkarkan, karena kedekatan mereka sudah memasuki enam tahun sehingga rasa trust yang mereka miliki juga sudah cukup stabil dan besar. Kadang Anton sedikit protes jika Tomi lama tak menyediakan waktu untuk mereka bertemu dan menikmati momen berdua dengan bertukar cerita. Biasanya mereka pergi ke tempat rekreasi yang berhubungan dengan alam bersama-sama seperti rafting, snorkeling dan diving. Selain itu kadang Tomi juga mengajak Anton untuk menghadiri acara yang diselenggarakan oleh teman Tomi.

Sedangkan konflik eksternal mereka tak pernah merasakan di-bully oleh masyarakat, karena di depan umum mereka bersikap dan berperilaku biasa layaknya dua orang sahabat. Karena dalam hubungan mereka tak diwarnai oleh ritual seksual pada pasangan gay lainnya. 


\section{Kesimpulan dan Saran}

\section{Kesimpulan}

Berdasarkan pemaparan pembahasan di atas, maka dapat ditarik kesimpulan, sebagai berikut :

1. Pasangan gay yang memiliki committed relationship memiliki keunikan dalam menjalin dan memelihara hubungan mereka, dan perbedaan etnis tidak mempengaruhi kualitas hubungan bahkan justru saling melengkapi dan menghargai keberagaman budaya masing-masing bangsa.

2. Kenyamanan adalah faktor penting dalam membina hubungan, sehingga bagi gay biseksual lebih merasakan enjoy saat bersama pasangan gay-nya daripada bersama sang istri.

3. Jenis pekerjaan pasangan gay ternyata bervariasi (PR Manager, Pilot, Marching Band Trainer \& Music Teacher, Lecturer, ICT Entrepreneur, dan Consultant). Padahal dahulu gay hanya terbatas pada pekerjaan di dunia entertainment atau salon.

4. Family Backgound tidak menjadi penyebab seseorang menjadi gay. Latar belakang keluarga para informan sangat bervariasi, ada yang happy family namun ada juga datang dari keluarga yang broken home.

5. Konflik internal yang terjadi dalam menjalin ikatan committed relationship pada pasangan gay, antara lain dipengaruhi oleh: 1) Karakter masing-masing pasangan yang saling melengkapi dapat meredakan konflik internal yang terjadi di antara mereka. 2) Perselingkuhan bisa saja terjadi dengan gay lainnya akibat kurang perhatian, rasa cemburu, maupun rasa cemas yang merasuki gay yang berselingkuh, karena takut ditinggalkan pasangannya. 3) Rasa cemas (security anxiety) di antara mereka kerap terjadi sebagai akibat takut kehilangan. Cara ampuh meredamnya biasanya dengan cara bertemu dan melakukan ritual seperti biasa mereka lakukan. 4) Salah satu gay (manly) tidak suka dengan gaya ngondhek/kecimpringan gay sissy/feminine.

6. Konflik eksternal yang dialami pasangan gay jika berkomunikasi dengan masyarakat adalah dalam bentuk stigma negatif, diskriminasi, dan bullying berupa kekerasan, pelecehan, dan penghinaan kepada kaum gay dan pasangan gay sering dilakukan oleh masyarakat baik dalam bentuk verbal maupun non verbal.

7. Bentuk komunikasi yang lebih sering dilakukan oleh pasangan gay yang berbeda bangsa ini adalah komunikasi non verbal dibandingkan komunikasi verbal. Komunikasi non verbal yang dilakukan adalah dalam bentuk ritual yang dilakukan pasangan gay yang memiliki committed relationship saat mereka bertemu adalah kissing, light petting, hard petting, intercourse dilakukan secara rutin atau kadangkadang saja, namun bahkan ada yang tidak melakukan hal tersebut sama sekali.

8. Relationship Bonding yang terjadi di antara pasangan gay tergantung pada pola hubungan dan kualitas hubungan di antara mereka. Pada pasangan ketiga, ikatan tidak terlalu kuat, di samping salah satu pasangan memilik istri dan anak, juga karena mereka tidak pernah melakukan ritual seksual, tetapi hanya spending 
time together dengan ngobrol, berolahraga, dan menonton film. Sedangkan pada pasangan kedua, ikatan sangat kuat namun sering juga terjadi konflik karena salah satu pasangan berselingkuh. Dan pada pasangan pertama, ikatan cukup kuat namun sering diwarnai salah paham karena rasa cemburu salah satu pasangan saat gay lainnya sedang menikmati kebersamaan dengan istri dan anaknya.

\section{Saran}

Diferensiasi kenyamanan yang dirasakan oleh gay biseksual saat bersama istri maupun bersama pasangan gay-nya menjadi penyebab seseorang bisa memiliki pasangan sejenis sekaligus lawan jenis, sehingga peneliti menyarankan agar dapat diantisipasi secara dini demi terciptanya keluarga bahagia.

Beberapa kasus bullying dan diskriminasi dilakukan masyarakat terhadap kalangan gay disebut sebagai gayphobia. Namun di sisi lain juga kerap terjadi penghinaan, ejekan, serta kekerasan yang dilakukan oleh kaum gay terhadap mantan gay atau gay yang sedang berproses menjadi hetero yang disebut sebagai Heterophobia. Permasalahan sosial ini harus menjadi perhatian keluarga terdekat, komunitas, masyarakat, dan negara.

\section{Daftar Rujukan}

Bajari, Atwar \& Sahala Tua Saragih. 2011. Komunikasi Kontekstual : Teori dan Praktik Komunikasi Kontemporer. Editor. Bandung : PT Remaja Rosdakarya.

Berger, Peter L. \& Luckmann, Thomas. 1990. Tafsir Sosial Atas Kebudayaan : Risalah tentang Sosiologi Pengetahuan. Terjemahan The Social Construction of Reality : A Treatise in The Sociology of Knowledge oleh Hasan Basri. Jakarta : LP3ES.

Boellstorff, Tom. 2005. The Gay Archipelago. New Jersey : Princeton University Press.

Denzin, Norman K, and Lincoln, Yvonna S. (Eds). 2009. Handbook of Qualitative Research. London: Sage Publication, Inc.

Fisher, Simon dkk. 2000. Working With Conflict : Skills and Strategies for Action. New York: Zed Book Ltd.

Foucault, Michael. 1997. The History of Sexuality. New York : Vintage Books.

Kuswarno, Engkus. 2011. Etnografi Komunikasi : Pengantar dan Contoh Penelitiannya. Bandung: Widya Padjadjaran.

Littlejohn, Stephen W. \& Karen A. Foss, 2011. Teori Komunikasi (Theories of Human Communication). Edisi 9. Jakarta: Salemba Humanika.

Miles, M.B., \& Huberman, A.M. 1992. Qualitative Data Analysis : an Expanded Source Book. Thousant Oaks CA : Sage Publication Inc. 
Mulyana, Deddy. 2007. Ilmu Komunikasi Suatu Pengantar. Bandung : PT Remaja Rosdakarya.

-------. 2001. Metode Penelitian Kualitatif : Paradigma Baru ilmu Komunikasi dan Ilmu Sosial Lainnya. Bandung : PT Remaja Rosdakarya.

Musdah, Mulia Siti. 2011. Fiqh Seksualitas : Risalah Isalam Untuk Pemenuhan Hak-hak Seksualitas. Jakarta : Perkumpulan Keluarga Berencana Indonesia.

Oetomo, Dede. 2001. Memberi Suara pada yang Bisu. Yogyakarta : Galang Printika, kerjasama Yayasan Adikarya IKAPI dengan The Ford Foundation.

Sinyo. 2014. Anakku Bertanya Tentang LGBT. Jakarta : PT Elex Media Komputindo Kompas - Gramedia.

Wood, Julia T. 2004. Interpersonal Communication : Everyday Encounter. Belmont: Wadsworth/Thomson Publishing.

\section{Media on-line}

Republika Online “Jakarta Darurat Gay”, diunduh 28 Agustus 2013

Kompasiana, "Potret Identitas Seksualitas dan Keberadaan Kaum Gay di Indonesia dalam Mengkonstruksikan Relasi melalui Situs Jaringan Komunitas Online", dimuat 14 Agustus 2013, diunduh pada 15 Agustus 2013.

http://indonesiaforum. com, diunduh 28 Agustus 2013.

www.eramuslim.com, diunduh pada 28 Agustus 2013.

\section{$\underline{\text { Majalah Komunitas }}$}

Outzine Edisi VI/Desember 2012

\section{$\underline{\text { Dokumentasi/Arsip }}$}

Arus Pelangi. 2013. Menguak Stigma, Kekerasan E Diskrimininasi pada LGBT di Indonesia : Studi Kasus di Jakarta, Yogyakarta dan Makassar. Jakarta : Arus Pelangi dalam Program Kemitraan bersama Komunitas Sehati Makassar, PLU Satu Hati Yogyakarta, The Swedish Federation for Lesbian, gay, Bisexual, and Transgender Rights (RFSL) Swedia dan Forum Syd.

Arus Pelangi. 2013. Mengenal Bullying. Jakarta : Anti Bullying Community Arus Pelangi. 